\title{
The Cultural Approach to the Management of the International Human Resource: An Analysis of Hofstede's Cultural Dimensions
}

\author{
Kwasi Dartey-Baah, $\mathrm{PhD}$ \\ Department of Organisation \& Human Resource Management, University of Ghana Business School \\ P.O. Box LG 78 Legon, Accra, Ghana, West Africa \\ Tel: 233-20-962-1292Ｅ-mail: kdartey-baah@ug.edu.gh
}

Received: December 14, 2012

Accepted: February 27, $2013 \quad$ Online Published: March 14, 2013

doi:10.5430/ijba.v4n2p39

URL: http://dx.doi.org/10.5430/ijba.v4n2p39

\begin{abstract}
The subject of culture has gained much prominence and attention in the management of international human resource. This paper examines the issues of culture, both national and organisational, reviews and discusses relevant literature and draws conclusions based on the issues at hand. The discussion of this paper is based on Hofstede's cultural dimensions. The findings of this paper revealed that elements contained in national cultures can transcend into organizational concerns. Moreover, not only are national cultures the main determinants of the success or failure of multinational businesses, but also organisational cultures. The paper advances that in dealing with matters of culture in the international domain, the point in question is how these cultural issues are managed and not the mere existence of the same that determines the success or failures of organisations.
\end{abstract}

Keywords: Hofstede, National culture, Organisational culture, Multi-national companies

\section{Introduction}

Culture affects and governs all facets of life by influencing values, attitudes and behaviours of a society. The culture of an organisation relates to the unique modes of carrying out their activities. Furthermore, the nature of organisational culture is largely influenced by the cultural orientations of the individuals forming it. Viewed as the socially transmitted behaviour patterns, norms, beliefs and values of a given community or organisations, culture is often seen as a source of conflict than of synergy Hofstede (1998). This conflict arises when people of different cultures interact with one another. In this light, the content of the organisational culture, which is either in line with or different from their respective cultural orientations, would determine to a large extent, the success or failure of the multinational business.

Culture is central in managing the current global workforce dynamics. Aguilera \& Dencker (2004) have divided culture into two distinct but overlapping groups; organisational cultures and national cultures. National and organisational culture can have a pervasive and powerful influence in organisations and in various aspects of global workforce management. Each culture is unique and those who find themselves in a particular culture imbibe it and it becomes an integral aspect of their lives. Such cultures may differ slightly or significantly from one organisation to the other.

A more critical issue in this categorization of cultures is that the success of mergers and acquisitions do not depend on the mere differences in culture (organisational or national); but how the cultural issues are managed (Harzing et al, 2011).

The success of mergers and acquisitions involving multinational companies to a large extent depends on the effective management of diverse cultures arising out of such ventures. For this reason, organisations engaged in cross-border mergers and acquisitions need to take into careful considerations cultural issues if they are to be successful. In managing human resources in the international settings some issues of paramount importance are; recruitment \& selection strategies, training, retention \& remuneration and exit strategies. In all these, culture is a key variable and a predictor of success or failure.

The assertion that if multinational companies want to be successful and maintain a competitive advantage in any international domain, they must adopt an organisational culture that is properly suited in the context of the national culture within which they operate is premised on the belief that leadership styles and behaviours are culture-bound 
(Kuada, 2010). It is against this backdrop that this paper seeks to examine the issues of culture based on Hofstede's cultural dimensions to explore the elements contained in national cultures that impact the overall performance in organisations. It assesses the influence culture, both national and organisational, has on international human resource practices and in its submission, reveals that an analogy between national culture and human resources practices is more likely to augment organisational performance.

\section{National Culture and Human Resource Practices}

The universality of human resource practices has been questioned. Human resource policies that may be successful in one jurisdiction may be unsuccessful in another. For instance, in an attempt to reach a desired outcome in human resource practice, salary structures may be effective in one country and proves ineffective in another. Similarly, quality circle programmes which are successfully used in Japan have not been effective in the United States (Newman \& Nollen, 1996).

National cultures influence strategic decisions and leadership styles (Schneider \& DeMeyer, 1991), as well as human resoure management practices such as performance appraisal (Luthans, Welsh \& Rosenkrantz, 1993). In cultures with high power distance, loyalty and obedience to those in higher authority is required, and, in fact, is the norm. In this case, management usually makes use of performance appraisal based on the behavioural criteria rather than results criteria. Additionally, drawing upon the Hofstede typology, it is not difficult to see how a nation's culture might impact on practices related to performance. For example, the United States scores 40 on power distance, which means moderate acceptance of status and hierarchy differences, while India scores 77 when measured against the world average of 56.5 Hofstede (1980). This suggests that individuals are more likely to accept without argument upward supervisor feedback in India than in the United States. As such a multinational company operating in both nations will have to adapt appropriate management practices and feedback mechanisms, as managers for example are less likely to be willing to receive downward feedback in India Harzing et al (2011). Similarly, in countries known for collectivist values like China, people prefer group-based, rather than individual-focused training (Earley, 1994) and according to Van de Vliert et al., (2004) may respond better to group-based, rather than individual-focused feedback.

Furthermore, a number of human resource practices have specific characteristics related to specific countries. For example, life-time employment policy is very popular in Japan, however, it is uncommon practice in USA. Also generally, Japanese companies spend more money for social activites and recreational facilities than that of American companies (Pascale \& Maguire, 1980).

A cross-cultural research involving 277 respondents in American companies, 291 Japanese companies, and 50 European companies by Kagono et al., (1985) in Smith (1992) concluded that Japanese companies have shorter hierarchical structures, flexible job descriptions, control systems built upon self-discipline and more promotions from within the organisation.

Laurent (1983) found that in Germany, decision making is more centralized than in United Kingdom. Besides, it is common for top positions in organisations in Germany to be occupied by an outsider. Meanwhile, companies in UK tended to have promotion from within policy, and spend more money for emoloyee well-being and middle management development programs.

Jaeger (1986) conducted research on the applicability of human resource parctices in developing countries and asserted that although there is a strong will to replicate western human resource policies, those policies cannot be implemented successfully. Besides, it is required that to be successfully practiced, those policies must fit with the assumptions of the local cultural context within which they seek to function.

\section{Organisational Culture and Human Resources Practices}

Organisational culture and the environmental factors in which an organisation exist determines the way of managing the organisation (Saffold, 1988). The relationship between organisational culture and human resources practices can be deduced from the interpaly of human behaviour in organisations in the face of prevailing organisational norms or cultures. When the members of organisations understand and internalise the organsational culture it enables them to choose strategy and behaviour that fit with their personality as well as organisational activities. This sets the tone for the emergence of organisational specific human resource practices reinforcing the fact that human resource practices are not universal. Where there is congruence between national culture and human resources practices, research shows a positive correlation between this particular outcome and organisational performance (Harzing et al (2011).

Research by Newman \& Nollen (1996) indicated that organisation performance is better in the companies where there is congruency between national culture and human resources practice. At the business unit level where 
conscious efforts are made to adopt human resource policies that are in conformity with the values and prescriptions of a country, the performance of such a business unit in terms of return on assets and return on sales is better, which may reflect in bigger and better bonuses for employees.

According to Earley (1994) if the human resource management practices are not in line with the basic tenets shared by employees, it will lead to dissatisfaction, lack of commitment and discomfort among the employees. On the contrary, when human resource practices fit with the values shared by employees, organisational performance is impacted positively.

\section{Hofstede's Cultural Dimensions and Managerial Implications}

Geert Hofstede defined national culture as the set of collective beliefs and values that distinguish people of one nationality from those of another. In his original comprehensive study conducted while working at IBM as a psychologist and involving over 100,000 individuals from 50 countries and three regions, Hofstede identified four important dimensions in national cultures. These dimensions are outlined as follows:

\subsection{Uncertainty Avoidance}

This dimension refers to the extent to which people feel comfortable when they are exposed to an ambiguous or uncertain situation. People in a low uncertainty avoidance society are more willing to take risks and appreciate flexibility and informality in the workplace. In contrast, people in a high uncertainty avoidance society tend to be risk-averse, and favour rigid and formal decision-making processes in the workplace.

The perceived difference in tolerating uncertain situations has several important implications at both macro and micro levels. Firstly, at the macro level, the acceptance of uncertainty is essential for innovation because it requires a tolerance for risk and change. On the other hand, at the micro or organisational level, in high uncertainty avoidance societies, numerous formal internal rules and regulations exist to control the work process of employees. In low uncertainty avoidance societies, managers are allowed to exercise more latitude and discretion in their decision-making rather than relying on rigid internal rules and regulations.

\subsection{Power Distance}

Power distance refers to what extent people have an equal distribution of power. In a large power distance culture, power is concentrated at the top in the hands of relatively few people while people at the bottom are subject to decisions and instructions given by superiors. Conversely, in a small power distance culture, power is rather equally distributed among the members of the society (House et al., 2002; 2004). Power distance as a concept has important implications in the organisational setting.

Firstly, managers in high power distance societies tend to believe in giving subordinates detailed instructions with little room for interpretation. Subordinates are supposed to respect the authority and superiority of upper management. Thus, the "mechanistic characteristics" of high power distance cultures, such as inequality among the members in the society, lack of free communication across different levels of the hierarchy, and centralized control can all stifle employee creativity and new ideas.

In contrast, low power distance societies are coupled with "organic characteristics," such as lack of hierarchical authority and less centralization which tend to promote employee interaction, lateral communication, and less emphasis on the rules. Non-directive, hands-off monitoring systems have often been implemented to allow the creativity and exploration necessary for successful innovation.

\subsection{Individualism vs. Collectivism}

This dimension is concerned with the degree to which individuals are integrated into groups. Individualism as a concept means that people seek and protect their own interests over the common goal of the society and their role in the society. In an individualistic culture, people are comfortable with having the authority to make a decision based on what the individual thinks is best. In individualistic societies, employees are provided with a great deal of personal freedom and autonomy.

However, in a collectivistic culture, people tend to belong to groups or collectives and look after each other in exchange for loyalty. Collective cultures thereby do not usually allow the freedom and independence necessary for organisational members to think creatively and, thereby, fail to cultivate an environment that fosters an innovative spirit.

Innovation is also curtailed upon since collective cultures are reluctant to accept variety and diversity in society. Moreover, the overwhelming and unconscious pressure for conformity and uniformity in collective cultures does not 
cultivate an environment for diversity, and provides less room for people to deviate from established norms, thus impeding the innovation process.

\subsection{Masculinity vs. Femininity}

This dimension deals with the distribution of emotional roles between the genders. Hofstede believes that the masculine dimension is very closely related to the concept of achievement motivation. A masculine culture is basically a performance driven society where rewards and recognition for performance are the primary motivational factors for achievement.

This type of culture tends to give the utmost respect and admiration to the successful achiever, who fulfills his ambition and demonstrates assertiveness and willingness to take risks in order to achieve goals. Top management positions are usually filled with men who tend to display characteristics of dominance and assertiveness which tend to be discouraged among women by societal gender norms.

On the other hand, in feminine cultures people tend to emphasize the quality of the "whole" life rather than money, success, and social status, which are easier to quantify. They are willing to reach out to the underprivileged and share their wealth with them. Overall, organisations with a feminine culture are not as competitive as those with a masculine culture, since the former places higher priority on concern for others and little distinction is made between men and women in the same position.

\subsection{Confucian Dynamism}

Using a different survey instrument called the Chinese Value Survey (CVS), Hofstede \& Bond (1988) identified a new cultural dimension, "long-term versus short-term orientation," that strongly reflects Confucianism, a cultural backbone of East Asian countries. Hofstede emphasized that this particular cultural dimension was missing in his original study and only relevant to countries in East Asia. Confucian dynamism may reflect a society's search for virtue rather than truth, truth being driven by religious ethics in Western countries.

Long-term orientation captures the following elements: adaptation of tradition to the modern context, high savings ratio driven by thrift, patience and perseverance towards slow results, and concern with respecting the demand of virtue. On the other hand, a short-term orientation contains the following aspects: respect for traditions, lower savings rate, quick results orientation, and concern with possessing the truth.

\subsection{Criticisms}

Hofstede's research has received several criticisms which are outlined below:

Firstly, the research may have been culturally bound since his research team, composed of Europeans and Americans, may have unintentionally influenced the analysis of the answers by their Western perspective.

Secondly, as mentioned already regarding regional and local subcultures, many countries have more than one culture. For example, the US has multiple regional and local subcultures, as the country consists of various ethnic groups and regional traditions, with a strong emphasis on local autonomy and individual states rights. Therefore, it may be presumptuous to generalize a certain country's culture. Lastly, most importantly, his findings may have lost explanatory power over the years since culture is not static and changes over time, albeit slowly.

\section{Implications of Hofstede's Study on International Human Resource Practices}

In multinational firms, there are occasions that call for new policies. Some of such policies involve risk to which the business must decide whether to continue with such a venture or opt out. Where the directors or the strategists are of a low uncertainty avoidance orientation, they are likely to go in for the deal though risky. On the other hand, those with a high uncertainty avoidance orientation would want to avoid any possible loss and so may not attempt the deal at all.

Taking leaders into consideration, those from high power distance cultures may tend to be very authoritative, and this may lead to problems, especially when such leaders are dealing with subordinates from low power distance cultures who expect leaders to come to the same level as their subordinates.

Group or team work is one of the key activities undertaken in many businesses. In the situation where individuals from both individualist and collectivist cultures are brought together to work as a team, challenges are likely to be faced because of the way each side would approach the issues at hand. For instance, while those from the individualistic culture may want to have their views implemented regardless of the views of others, those from the collectivist culture would want collaboration and mutuality. 
Again when it comes to working out the long-term objectives of the organisation, views as to what should be the main focus may differ, depending on whether the individual is of a masculine or feminine-centered culture or orientation. Thus while the feminine culture will focus on holistic aspects, the masculine culture will emphasize success, achievement, social status, and quantifiable realities.

Businesses in the global environment have no option but to be dynamic (change) if they are to be relevant to the fast moving times particularly in the business world. It therefore suggests that at a point the way businesses do things might have to change. The level of acceptance of this new change depends on the orientation of the people within the organisation. In this case, those of the long-term orientation would be willing to adapt to new situations while those of the short-term orientation would want to maintain the existing culture and so would resist any change efforts.

The above issues raised point to the fact that in any situation that involves the human resource, such as decision making, responding to change, leadership, team work and risk taking, issues of culture may arise, especially in multinational businesses that are made up of individuals from different countries, thus different cultural orientations. With the human resource viewed as the most important asset of businesses with which success can be attained (Armstrong, 2006), the issues of culture that directly relates to the people must not be neglected. It must be emphasized that in the event of cultural diversities, success can only be attained through effective management of the cultural issues.

\section{Conclusion}

All over the world multi-national companies find themselves in cultures different from their parent country cultures and therefore call for such companies having to deal with different cultural orientations. The success of such firms can as such be impacted by how these are handled. This is because human institutions such as businesses cannot exist without culture, that is, the "how-we-do-it-here" phenomenon. It is therefore important that cultural issues are adequately given the needed attention if such organisations are to succeed particularly in a competitive business environment.

The author proposes three approaches critical to the success of multinational companies in the handling of cultural issues in organisations.

The first approach in tackling the cultural challenges is the "Hybridisation of culture" where aspects of the culture of dominant nationals are interwoven into a common culture of the organisation. This will require the involvement of all relevant stakeholders in ensuring that decisions taken are holistic and largely agreed upon by all.

The second approach can be by "Culture adoption" an organisational culture strategy that involves the adoption of the culture of one of the parties involved. Thus the organisational culture of the acquiring firm or "acquiree" (in the case of mergers and acquisitions) or of the parent company or subsidiary (in the case of multinational business), as agreed by the consenting parties, can be institutionalized as the corporate culture by which all must abide by. Ignoring such considerations and focusing mainly on potential financial gains which often tend to be the oil that drives the wheels of investment both at the domestic and international levels can spelled the doom of businesses with untold repercussions.

The third approach to addressing and handling the challenges that cultural issues posed to organisations is the "Creation of a new culture". This may appear to be a more extreme form of forming organisational culture whereby new systems, rules and procedures, as well as norms are created. In pursuing this approach, attention should not necessarily be paid to the existing cultures of the stakeholders but rather efforts must be directed more towards the creation of the new culture with the strategic intent of enabling the multinational business to attain its long-term goals and objectives.

It is worth emphasising that the aim of organisational culture is to ensure that there is an agreed and uniform way of doing things in organisations so as to minimise all possible conflicts due to cultural differences. Planned interventions must therefore also be in place to ensure that where there are deviations from agreed norms, corrective actions are immediately taken. Clearly multinational companies cannot ignore such considerations if they are to operate successful in the international domain.

\section{References}

Armstrong. M. (2006). Handbook of Human Resource Management Practice (10th ed.). London: Kogan Page.

Bae, J., \& Lawler, J. J. (2000). Organisational and HRM Strategies in Korea: Impact on Firm Performance in An Emerging Economy. Academy of Management Journal, 43(3), 502 - 517. http://dx.doi.org/10.2307/1556407 
Dartey-Baah, K., (2011). The impact of national cultures on corporate cultures in organisations. Academic Leadership Journal, 9(1).

Delaney, J.T., \& Huselid, M. A. (1996). The Impact of Human Resources Management Practices on Perceptions of Organisational Performance. Academy of Management Journal, 39(4), 949 - 969. http://dx.doi.org/10.2307/256718

Dessler, Gary. (1997). Manajemen Sumber Daya Manusia. Penerjemah Triyana Iskandarsyah. Penerbit PT. Prenhallindo Jakarta.

Earley, P.C. (1994). Self or Group? Cultural effects of training on self-efficacy and performance. Administrative Science Quarterly, 39(1), 89-117. http://dx.doi.org/10.2307/2393495

Early, P. C. (1987). Intercultural Training for Managers: A Comparison of Documentary and Interpersonal Methods. Academy of Management Journal, 30, 685-698. http://dx.doi.org/10.2307/256155

Ferdinand, A. (2002). Structural Equation Modeling dalam Penelitian Manajement, Edisi 2. Semarang: BP Undip.

Geringer, M. J., Frayne, A. C., \& Milliman, F. J. (2002, Spring). In Search of "Best Practices" in International Human Resource Management: Research Design and Methodology. Human Resource Management, 41(1), 5-30. http://dx.doi.org/10.1002/hrm.10017

Hair, F.J., Anderson E.R., Tatham L.R., \& Black C. W. (1998). Multivariate Data Analysis (5 ${ }^{\text {th }}$ ed.). Prentice Hall International Inc.

Harzing et al. (2011). International Human Resource Management ( $3^{\text {rd }}$ ed.). Sage Publications, India Pvt Ltd.

Harzing, A. (2001). An analysis of the functions of international transfer of managers in MNCs. Employee Relations, 23(6), 581-598. http://dx.doi.org/10.1108/01425450110409248

Hofstede, G. (1980). Culture's Consequences. International Differences in Work-Related Values. A Bridged Edition. Sage Publication. Newburry Park.

Hofstede, G. (1980). Motivation, Leadership, and Organisation: Do American Theories Apply Abroad? Organisational Dynamics, Summer, AMACOM, A Division of American Management Association.

Hofstede, G. (1990). A Reply \& Comment on Joginder P Singh: Managerial Culture and Work-related Values in India. Organisation Studies, 11/1(103-106), 1-5.

Hofstede, G. (1997). Cultures and Organisations, Software of the Mind. Intercultural Cooperation and its Importance for Survival. McGraw Hill. New York.

Hofstede, G. (1998). Identifying organisational subcultures: An empirical approach. Journal of Management Studies, 35(1), 17-28. http://dx.doi.org/10.1111/1467-6486.00081

Hofstede, G. (2001). Culture's Consequences: comparing values, behaviors, institutions, and organisations across nations ( $2^{\text {nd }}$ ed.). Thousand Oaks, CA: SAGE Publications.

Hofstede, G., \& Hofstede, J. (2005). Cultures and organisations: software of the mind (Revised and expanded $2^{\text {nd }}$ ed.). New York: McGraw-Hill.

Hofstede, G., \& M. H. Bond. (1984). Hofstede's Culture Dimensions: An Independent Validation Using Rokeach's Value Survey. Journal of Cross-Cultural Psychology, 15(4), 417-433. http://dx.doi.org/10.1177/0022002184015004003

Hofstede, G., \& M. H. Bond. (1988). The Confucius connection: From cultural roots to economic growth. Organisational Dynamics, 16(4), 5-21. http://dx.doi.org/10.1016/0090-2616(88)90009-5

House, R., Hanges, P, Javidan, M., Dorfman, P., \& Gupta, V. (2004). Culture, Leadership, and Organisations: The GLOBE Study of 62 Societies. Thousand Oaks, CA: Sage.

House, R., Javidan, M., Hanges, P., \& Dorfman, P. (2002). Understanding cultures and implicit leadership theories across the globe: An introduction to project GLOBE. Journal of World Business, 37, 10. http://dx.doi.org/10.1016/S1090-9516(01)00069-4

Jaeger, A. M. (1986). Organisation Development and National Culture: Where's the Fit? Academy of Management Review, 11, 178-190.

Kuada, J. (2010). Culture and leadership in Africa: a conceptual model and research agenda. African Journal of Economic and Management Studies, 1(1), 9-24. http://dx.doi.org/10.1108/20400701011028130 
Laurent A. (1986). The Cross Cultural Puzzle of International Human Resources Management. Human Resource Management, 15, 91-102. http://dx.doi.org/10.1002/hrm.3930250107

Lowe, B.K, Milliman, J, De Cieri, H., \& Dowling, J. P. (2002, Spring). International Compensation Practices: A Ten Country Comparative Analysis. Human Resource Management, 41(1), 45-66. http://dx.doi.org/10.1002/hrm.10019

Luthans, F., D.H.Welsh, \& Rosenkrantz, S.A. (1993). What do Russian Managers Really Do? An Observational Study with Comparison to US Managers. Journal of International Business Studies, 24(4), 741-762. http://dx.doi.org/10.1057/palgrave.jibs.8490253

Newman, L.K., \& Nollen, D.S. (1996). Culture and Congruence: The Fit Between Management Practice and National Culture. Journal of International Business Studies, Fourth Quarter, 27(4), 753-779. http://dx.doi.org/10.1057/palgrave.jibs.8490152

Pascale, R. T., \& Maguire, M. A. (1980). Comparison of Selected Work Factors in Japan and The United States. Human Relations, 33, 433-455. http://dx.doi.org/10.1177/001872678003300701

Saffold, Guy. (1988). Culture Traits, Strength and Organisational Performance: Moving Beyond Strong Culture. Academy of Management Review, 13(4), 546-558.

Schneider, S. C., \& DeMeyer, A. (1991). Interpreting and Responding to Strategic Issues: The Impact of National Culture. Strategic Management Journal, 12, 307-320. http://dx.doi.org/10.1002/smj.4250120406

Schuler, S. R. \& Jackson, S. E. (1996). Human Resource Management. New York: Prentice Hall.

Smith, P. B. (1992). Organisational Behaviour and National Cultures. British Journal of Management, 3, 39-51. http://dx.doi.org/10.1111/j.1467-8551.1992.tb00034.x

Van De Vliert, E., Shi, K., Sanders, K., Wang, Y., \& Huang, X. (2004). Chinese and Dutch interpretations of supervisory feedback. Journal of Cross-Cultural Psychology, 35, 417-435. http://dx.doi.org/10.1177/0022022104266107 